\title{
KEEFEKTIFAN MODEL PEMBELAJARAN KONTEKSTUAL TERHADAP KEMAMPUAN MENULIS TEKS PIDATO SISWA KELAS XI MADRASAH ALIYAH PATRA MANDIRI PALEMBANG
}

\author{
AGUS HERU \\ 0216087401 \\ Dosen Universitas PGRI Palembang \\ agusherumasdulhak@yahoo.com
}

\begin{abstract}
ABSTRAK
Masalah dalam penelitian ini adalah "Keefektifan Model Pembelajaran Kontekstual Terhadap Kemampuan Menulis Teks Pidato Siswa Kelas XI Madrasah Aliyah Patra Mandiri Palembang”. Permasalahan dalam penelitian ini adalah bagaimanakah Keefektifan Model Pembelajaran Kontekstual Terhadap Kemampuan Menulis Teks Pidato Siswa Kelas XI Madrasah Aliyah Patra Mandiri Palembang. Tujuan dalam penelitian ini untuk mengetahui dan mendeskripsikan Keefektifan Model Pembelajaran Kontekstual Terhadap Kemampuan Menulis Teks Pidato Siswa Kelas XI Madrasah Aliyah Patra Mandiri Palembang. Metode yang digunakan dalam penelitian ini adalah metode eksperimen dan teknik pengumpulan data ini adalah teknik tes dan teknik wawancara. Sampel penelitian berjumlah 32 siswa diambil dengan cara sistematis menggunakan interval 10 dari 173 jumlah populasi. Hasil penelitian menunjukkan rata-rata tes akhir yaitu diperoleh nilai sebesar 84. Sedangkan jumlah rata-rata tes awal diperoleh nilai sebesar 45. Maka Hasil pengujian hipotesis diketahui bahwa $t_{\text {hitung }}=10,64 \mathrm{dan} d \mathrm{~b}=60$ dalam $\mathrm{t}_{\text {tabel }}$ harga $\mathrm{t}$ kritiknya terletak pada $0,05=10,64$. Jadi, dinyatakan bahwa $\mathrm{t}_{\text {tabel }}<\mathrm{t}_{\text {hitung }}=1,67<10,64$ sehingga $\mathrm{t}_{\text {hitung }}$ dinyatakan signifikan. Dengan demikian $\mathrm{H}_{0}$ ditolak dan $\mathrm{H}_{\mathrm{a}}$ diterima.
\end{abstract}

Kata Kunci: Model Kontekstual, Menulis Teks Pidato.

\section{THE EFFECTIVENESS OF CONTEXTUAL LEARNING MODELS ABOUT THE SPEECH OF WRITING TEXT SPEECH OF CLASS XI MADRASAH STUDENTS ALIYAH PATRA MANDIRI PALEMBANG}

\begin{abstract}
The problem in this study was "The Effectiveness of Contextual Learning Models on the Ability to Write the Speech Text of Students in Class XI Madrasah Aliyah Patra Mandiri Palembang". The problem in this research is how the Effectiveness Model of Contextual Learning Ability Of Writing Text To Speech Student Class XI Madrasah Aliyah Patra Mandiri Palembang. The aim in this study to determine and describe the Effectiveness Model of Contextual Learning Ability Of Writing Text To Speech Student Class XI Madrasah Aliyah Patra Mandiri Palembang. The method used in this study is the experimental method and data collection techniques are test techniques and interview techniques. The sample of 32 students was taken systematically using intervals of 10 out of 173 population. The results showed an average of the final test is obtained a value of 84 . While the average number of initial tests obtained a value of 45 . Then the results of hypothesis testing known that $t=10.64$ and $\mathrm{db}=60$ in his criticism ttabel $\mathrm{t}$ price is at $0,05=10.64$. So, it is stated that table <thitung $=1.67<10.64$ so that tcount is significant. Thus $\mathrm{HO}$ is rejected and $\mathrm{Ha}$ is accepted.
\end{abstract}

Keywords: Contextual Model, Writing Speech Text 


\section{A. PENDAHULUAN}

Bahasa adalah alat komunikasi yang digunakan oleh setiap individu dalam kehidupan sehari-hari. Bahasa juga dikatakan sebagai satuan ujaran yang dihasilkan oleh alat ucap manusia sebagai lambang bunyi yang bersifat arbitrer dan memiliki satuan arti yang lengkap. Dengan bahasa itulah manusia dapat saling berinteraksi satu sama lain, interaksi itu sendiri adalah berkomunikasi.

Dengan Menulis inilah seseorang dapat mengungkapkan ide/gagasan dalam bentuk karangan secara leluasa. Pada dasarnya, ada empat keterampilan berbahasa yang harus dimiliki setiap siswa sebagai hasil belajar. Keempat jenis keterampilan tersebut yakni menyimak, berbicara, membaca, dan menulis. Keempat aspek ini dalam penggunaannya sebagai alat komunikasi tidak dapat berdiri sendiri, satu sama lain saling berkaitan dan saling menentukan.

Hasil belajar pada dasarnya merupakan kemampuan yang dimiliki siswa setelah menerima perlakuan dari pengajaran guru yang dapat memberikan perubahan tingkah laku baik pengetahuan maupun pemahaman, sikap, serta keterampilan siswa sehingga menjadi lebih baik dari sebelumnya. Hasil belajar siswa pada mata pelajaran bahasa Indonesia masih mengalami keterhambatan di dalam menulis pidato.

Dalam sistem pendidikan di Indonesia, pelajaran bahasa Indonesia adalah mata pelajaran yang sangat penting. Pada setiap jenjang pendidikan pelajaran bahasa Indonesia. Menurut Dalman (2015:3), keterampilan menulis merupakan suatu kegiatan komunikasi berupa penyampaian pesan (informasi) secara tertulis kepada pihak lain dengan menggunakan bahasa tulis sebagai alat atau medianya.

Aktivitas menulis melibatkan beberapa unsur, yaitu: penulis sebagai penyampaian pesan, isi tulisan, saluran atau media, dan pembaca. Menurut Tarigan (2008:3), keterampilan menulis merupakan suatu keterampilan berbahasa yang dipergunakan untuk berkomunikasi secara tidak langsung, tidak secara tatap muka dengan orang lain. Menulis merupakan suatu kegiatan yang produktif dan ekspresif.

Selain itu, Menurut Wardarita (2015:5), menulis adalah suatu bentuk komunikasi tersendiri yang ditujukan untuk ketidaktahuan pembaca, penulis biasanya lebih memikirkan apa yang akan dikomunikasikan daripada kepada siapa penulis berkomunikasi. Menurut Suprijono (2016:98) model pembelajaran kontekstual merupakan konsep yang membantu guru mengaitkan antara materi yang diajarkannya 
dengan situasi dunia nyata dan mendorong peserta didik membuat hubungan antara pengetahuan yang dimilikinya dengan penerapannya dalam kehidupan mereka sebagai anggota keluarga dan masyarakat.

Menurut Aqib (2013:4) model pembelajaran kontekstual merupakan suatu proses pendidikan yang bertujuan memotivasi siswa. Pembelajaran ini digunakan untuk memahami makna materi pelajaran yang dipelajari dengan mengkaitkan materi tersebut dalam konteks kehidupan mereka sehari-hari (konteks pribadi, dan sosial)

Menurut Wardarita (2012:37), model pembelajaran kontekstual adalah konsep belajar yang diajarkan dengan situasi dunia nyata siswa dan mendorong siswa membantu hubungan antara pengetahuan yang dimiliki siswa dengan penerapannya dengan kehidupan mereka sebagai anggota keluarga dan masyarakat.

Model ini memberikan kesempatan kepada guru untuk mengembangkan kinerja profesionalnya dengan menggunakan tujuh prinsip pembelajaran kontekstual yang harus dikembangkan oleh guru.

(1) Konstruktivisme (constructivism) strategi untuk mempelajari konsep seberapa banyak pengetahuan yang harus diingat siswa.

(2) Bertanya (questioning) kebiasaan untuk bertanya siswa.

(3) Menemukan (inquiry) sistem pembelajaran yang membantu siswa untuk menemukan sendiri sesuai dengan pengalaman masing-masing.

(4) Pemodelan (modeling) memberikan model/contoh dijadikan alternatif untuk mengembangkan pelajaran bagi siswa.

(5) Masyarakat belajar (learning community) membiasakan siswa untuk melakukan kerjasama dengan orang lain (belajar dalam kelompok).

(6) Refleksi (reflection) apa yang baru terjadi atau baru saja dipelajari.

(7) Penilaian otentik (authentic assessment) penilaian dilakukan saat latihan.

Berdasarkan uraian tersebut, peneliti tertarik meneliti keefektifan model pembelajaran kontekstual terhadap kemampuan menulis teks pidato. Peneliti memilih untuk meneliti di Kelas XI Madrasah Aliyah Patra Mandiri Palembang.

Di dalam Kurikulum 2013 terdapat kompetensi dasar (KD) tentang menulis teks pidato, teks pidato adalah salah satu cara untuk mengetahui keefektifan model pembelajaran kontekstual dalam pembelajaran menulis teks pidato. peneliti memilih siswa kelas XI Madrasah Aliyah Patra Mandiri Palembang karena disekolah tersebut 
belum pernah diteliti tentang keefektifan model pembelajaran kontekstual dalam pembelajaran menulis teks pidato.

\section{B. TINJAUAN PUSTAKA}

\section{Model Pembelajaran}

Menurut Suprijono (2016:64) model pembelajaran adalah pola yang digunakan sebagai pedoman dalam merencanakan pembelajaran di kelas maupun tutorial. Menurut Soekamto (dikutip Shoimin, 2014:23) model pembelajaran adalah kerangka konseptual yang melukiskan prosedur yang sistematis dalam mengorganisasikan pengalaman belajar untuk mencapai tujuan belajar tertentu, dan berfungsi sebagai pedoman bagi para perancang pembelajaran dan para pengajar dalam merencanakan aktivitas belajarmengajar. Menurut Trianto (2009), http://www.landasanteori.com/2015/09/pengertianmodel-pembelajaran-definisi .html) "Model pembelajaran merupakan pendekatan yang luas dan menyeluruh serta dapat diklasifikasikan berdasarkan tujuan pembelajarannya, sintaks (pola urutannya), dan sifat lingkungan belajarnya.

\section{Model Pembelajaran Kontekstual}

Berms dan Erikson (dikutip Komalasari, 2014:6) mengemukakan bahwa pembelajaran kontekstual merupakan konsep belajar dan mengajar yang membantu guru mengaitkan antara materi yang diajarkannya dengan situasi dunia nyata siswa dan mendorong siswa membuat hubungan antara pengetahuan yang dimilikinya dengan penerapannya dalam kehidupan mereka sebagai anggota keluarga, warga negara, dan pekerja. selain itu, Johnshon (dikutip Komalasari, 2014:6) menjelaskan bahwa pembelajaran kontekstual adalah suatu pembelajaran yang memungkinkan siswa menghubungkan isi materi dengan konteks kehidupan sehari-hari untuk menemukan makna. Berdasarkan uraian tersebut dapat disimpulkan bahwa pembelajaran kontekstual merupakan konsep belajar yang membantu guru mengaitkan antara materi yang diajarkan dengan situasi nyata siswa dan mendorong siswa membuat hubungan antara pengetahuan yang dimilikinya dengan penerapan dalam kehidupan mereka sehari-hari. 


\section{Karakteristik Pembelajaran Kontekstual}

Komalasari (2014:13) mengemukakan bahwa pembelajaran kontekstual memiliki beberapa karakteristik, yaitu: (1) pembelajaran yang menerapkan konsep keterkaitan (relating), (2) konsep pengalaman langsung (experiencing); (3) konsep (applying); (4) konsep kerja sama (cooperating); (5) konsep pengaturan diri (selfregulating); dan (6) konsep penilaian autentik (aunthentic assessment). Berikut enam karakteristik pembelajaran kontekstual tersebut.

(1) Keterkaitan (relating)

Pembelajaran yang menerapkan konsep keterkaitan (relating) adalah proses pembelajaran yang memiliki keterkaitan (relevansi) dengan bekal pengetahuan yang telah ada pada diri siswa dan dengan pengalaman dalam kehidupan dunia nyata siswa

(2) Pengalaman langsung (experiencing)

Pembelajaran yang menerapkan pengalaman langsung (experiencing) adalah proses pembelajaran yang memberikan kesempatan pada siswa untuk mengkontruksi pengetahuan dengan cara menemukan dan mengalami sendiri secara langsung.

(3) Aplikasi (appliying)

Proses pembelajaran yang menerapkan konsep aplikasi (appliying) adalah proses pembelajaran menekankan pada penerapan, fakta, konsep, prinsip, dan prosedur yang dipelajari dalam situasi dan konteks.

(4) Kerja sama (cooperating)

Pembelajaran yang menerapkan konsep kerja sama adalah pembelajaran yang mendorong kerja sama di antara siswa, antara siswa dengan guru dan sumber belajar.

(5) Pengaturan diri (self-regulating)

Pembelajaran yang menerapkan konsep pengaturan pengaturan diri (selfregulating) adalah pembelajaran yang mendorong siswa untuk mengatur diri dan pembelajarannya secara sendiri.

(6) Asemen autentik (aunthentic assesment)

Pembelajaran yang menerapkan konsep asesmen autentik adalah pembelajaran yang mengukur, memonitor, dan menilai semua aspek hasil belajar 
(yang tercakup dalam domain kognitif, afektif, dan psikomotorik), baik yang tampak sebagai hasil akhir dari suatu proses pembelajaran maupun berupa perubahan dan perkembangan aktivitas, dan perolehan belajar selama proses pembelajaran di dalam kelas ataupun di luar kelas.

\section{Komponen-Komponen Pembelajaran Kontekstual}

\section{a. Konstruktivisme (contructivisme)}

Konstruktivisme merupakan landasan berpikir (filosofi) dalam pembelajaran kontekstual. Pembelajaran yang berciri konstruktivisme menekankan pada pemahaman sendiri secara aktif, kreatif, dan produktif.

Siswa membangun sendiri pengetahuan mereka melalui keterlibatan aktif dalam proses belajar dan mengajar. Siswa menjadi pusat kegiatan bukan guru.

\section{b. Menemukan (inquiry)}

Menemukan merupakan bagian inti dari kegiatan pembelajaran kontekstual. Pengetahuan dan keterampilan yang diperoleh siswa diharapkan bukan hasil mengingat seperangkat fakta-fakta. Guru harus merancang kegiatan yang merujuk pada kegiatan menemukan apapun materi yang diajarkan, siklus inkuiri meliputi: (1) observasi (observation), (2) bertanya (questenning), (3) mengajukan dengan (hipotesis), (4) mengumpulkan data (data gathering), dan (5) menyimpulkan (conclusion).

Langkah-langkah kegiatan menemukan (inkuiri) adalah sebagai berikut.

1) Merumuskan masalah (dalam mata pelajaran apapun).

2) Mengamati atau melakukan observasi.

3) Menganalisis dan menyajikan hasil dalam tulisan, gambar, laporan, tabel dan karya lainnya.

4) Mengkomunikasikan atau menyajikan hasil karya pada pembaca, teman sekelas, guru atau orang lain.

\section{c. Bertanya}

Bertanya (questioning) merupakan strategi utama pembelajaran kontekstual, bertanya dalam pembelajaran dipandang sebagai kegiatan guru untuk mendorong, membimbing, dan menilai kemapuan berpikir siswa, dalam sebuah pembelajaran yang produktif, kegiatan bertanya berguna untuk: (1) menggali informasi, baik administrasi maupun akademis; (2) mengecek pemahaman siswa (3) membangkitkan respon kepada 
siswa (4) mengetahui sejauh mana keingintahuan siswa (5) mengetahui hal-hal yang sudah diketahui siswa (6) memfokuskan perhatian siswa pada sesuatu yang dikehendaki guru (7) untuk membangkitkan lebih banyak lagi pertanyaan dari siswa (8) untuk menyegarkan kembali pengetahuan siswa.

\section{d. Masyarakat Belajar (learning comumnity)}

Konsep masyarakat belajar (learning community) menyarankan agar hasil pembelajaran diperoleh dari kerja sama dengan orang lain. Hasil belajar diperoleh dari sharing antara teman, antara kelompok, dan antara yang tahu dengan yang belum tahu yang cepat menangkap dan mendorong temannya yang lambat, yang mempunyai gagasan segera memberi usul dan seterusnya.

Model pembelajaran dengan teknik learning community ini sangat membantu proses pembelajaran di kelas. Praktiknya dalam pembelajaran terwujud dalam (1) pembentukan kelompok kecil (2) pembentukan kelompok besar (3) mendatangkan ahli ke kelas (tokoh olahragawan, dokter, perawat, petani, pengurus organisasi, polisi, dan sebagainya (4) bekerja dengan siswa dari kelas sederajat (5) bekerja kelompok dengan siswa kelas di atasnya, dan (6) bekerja dengan masyarakat.

\section{e. Pemodelan (modelling)}

Dalam pembelajaran kontekstual guru bukan satu-satunya model. Model dapat dirancang dengan melibatkan siswa. Seorang siswa bisa ditunjuk untuk memberi contoh temannya cara menggunakan alat peraga, siswa sebagai contoh tersebut dikatakan sebagai model. Model juga dapat didatangkan dari luar kelas.

\section{f. Refleksi (reflection)}

Refleksi adalah cara berpikir tentang apa yang baru dipelajari atau berpikir ke belakang tentang apa-apa yang sudah dilakukan di mana yang lalu. Refleksi merupakan respon terhadap kejadian, aktivitas, atau pengetahuan yang baru diterima. Pada akhir pembelajaran guru menyisakan waktu sejenak agar siswa melakukan refleksi. Realisasi refleksi dapat berupa (1) pernyataan langsung tentang apa-apa diperolehnya hari itu (2) catatan atau jurnal di buku siswa (3) kesan atau saran siswa mengenai pembelajaran itu (4) diskusi, dan (5) hasil karya.

\section{g. Penilaian yang sebenarnya (authentic assessment)}

Penilaian adalah proses pengumpulan berbagai data yang memberikan gambaran perkembangan siswa. Apalagi data yang dikumpulkan guru mengidentifikasikan bahwa 
siswa mengalami kemacetan belajar, maka guru segera mengambil tindakan yang tepat agar siswa terbebas dari kemacetan belajar.

Karakter pembelajaran kontekstual adalah (1) antara siswa perlu kerjasama, (2) saling menunjang, (3) menyenangkan dan tidak membosankan, (4) belajar dengan minat yang tinggi, (5) terintegrasi, (6) menggunakan berbagai sumber, (7) siswa aktif, (8) sharing dengan, (9) siswa kritis dan kreatif, (10) dinding kelas dan lorong-lorong penuh dengan hasil karya siswa, peta-peta, artikel, humor, dan lain-lain, (11) laporan kepada orang tua bukan hanya rapor, tetapi juga hasil karya siswa, hasil praktikum, karangan siswa, dan lain-lain, dikemas dalam portofolio, dan (12) menggunakan penilaian sebenarnya.

\section{Langkah-Langkah Pembelajaran Menulis Teks Pidato Dengan Menggunakan Model Pembelajaran Kontekstual Komponen Pemodelan}

Menulis merupakan keterampilan yang harus dilatih, karena menulis bukan merupakan keterampilan alami. Oleh karena itu, bagi setiap penulis diharapkan untuk dapat menuangkan ide dan dan gagasan nya dengan baik dan jelas agar pembaca tidak bingung dalam membacanya. Menulis adalah suatu bentuk komunikasi tersendiri yang ditunjukan untuk mengomunikasikan pikiran, perasaan, dan kemauan, sehingga dapat dimengerti oleh pembaca (Wardarita, 2014:5).

Model pembelajaran yang digunakan dalam pembelajaran menulis teks pidato adalah model pembelajaran kontekstual komponen pemodelan. Kaitan antara pembelajaran menulis teks pidato dengan model pembelajaran ini adalah terdapat pada langkah pembelajarannya. Langkah -langkah yang dilakukan oleh guru adalah Guru menjelaskan cara menulis teks pidato kepada siswa,Siswa dibentuk dalam kelompok kecil (Heterogen), Siswa menuliskan teks pidato dengan tema yang sudah ditentukan guru dalam kelompok masing-masing, Siswa berdiskusi menyusun kerangka isi pidato, Siswa berdiskusi menyusun teks pidato berdasarkan kerangka isi pidato, Siswa bertukar kerjaan dan mengoreksi hasil tulisan teks pidato kelompok lain, Siswa merevisi dan memperbaiki tulisan teks pidato kelompoknya berdasarkan masukan dari kelompok lain, Guru dan siswa mengadakan refleksi tentang proses belajar yang telah dilakukan.

\section{Pidato}

Pidato merupakan sebuah kegiatan berbicara di depan umum atau berorasi untuk menyatakan pendapatnya atau memberikan gambaran tentang suatu hal. Pidato biasanya dibawakan oleh seorang yang memberikan orasi-orasi dan pertanyaan tentang suatu hal. 
Menurut Sugono dkk (2013:1071) pidato adalah pengungkapan pikiran dalam bentuk kata-kata yang ditujukan kepada orang banyak, wacana yang disiapkan untuk diucapkan di depan khalayak.

Menurut Mairu (2006:9) mengemukakan berpidato adalah kegiatan berbicara atau penyampaian/penyajian lisan yang dilakukan oleh seseorang kepada orang banyak secara sepihak untuk mengkomunikasikan pikiran dan atau perasaan tertentu.

Sementara, menurut Ismawati (2012:32) pidato merupakan pengungkapan pikiran dalam bentuk kata-kata secara lisan yang ditujukan kepada orang banyak. Selain itu, Menurut Wiyanto (2012:11) berpidato adalah kegiatan berkomunikasi satu arah, dari pembicara kepada para pendengar, pembicara menyampaikan informasi dan pendengar menerima informasi.

Oleh karena itu, berpidato memerlukan dan mementingkan ekspresi gagasan dan penalaran dengan menggunakan bahasa lisan yang didukung oleh aspek non-bahasa, seperti ekspresi, wajah, kontak pandang dan intonasi suara. Berdasarkan pendapatpendapat tersebut dapat disimpulkan bahwa pidato adalah suatu penyampaian dan pemahaman pikiran informasi atau gagasan baik secara lisan maupun tulisan yang disampaikan melalui pembicaraan kepada khalayak ramai.

\section{METODE PENELITIAN}

Penelitian di Madrasah Aliyah Patra Mandiri Jl.D.I Panjaitan Plaju Ilir, Kota Palembang, Sumatera Selatan. Metode penelitian adalah cara yang digunakan oleh peneliti dalam mengumpulkan data penelitiannya. (Arikunto, 2014:203). Metode yang digunakan dalam penelitian ini adalah metode eksperimen. Kelompok eksperimen dalam penelitian ini adalah kelompok siswa yang memperoleh pembelajaran dengan model pembelajaran kontekstual. Berdasarkan pendapat tersebut, maka dalam penelitian ini metode yang akan digunakan adalah metode eksperimen. Populasi penelitian ini adalah semua kelas XI Madrasah Aliyah Patra Mandiri Palembang yang berjumlah 173 orang yang terdiri atas laki-laki dan siswa perempuan. Sampel adalah bagian dari jumlah dan karakteristik yang dimiliki oleh populasi tersebut. bila populasi besar, dan peneliti tidak mungkin mempelajari semua yang ada pada populasi, misalnya karena keterbatasan dana,tenaga dan waktu, maka penelitian dapat menggunakan sampel yang diambil dari populasi itu. (Sugiyono, 2017:81). 
Sampel yang digunakan pada penelitian ini adalah sampel random sampling (sampel acak) karena pengambilan anggota sampel dari populasi dilakukan secara acak tanpa memperhatikan strata yang ada dalam populasi itu. Teknik pengumpulan data dilakukan dengan cara tes dan wawancara

\section{HASIL PENELITIAN DAN PEMBAHASAN}

Dari hasil analisis data penelitian yang telah dilakukan peneliti dengan cara menyuruh siswa menulis teks pidato, bahwa peserta didik pada tes akhir yang menggunakan model kontekstual pada menulis teks pidato mendapat hasil lebih baik dibandingkan pada tes awal yang tidak menggunakan model pembelajaran kontekstual pada menulis pidato. Hal ini diketahui dari jumlah rata-rata tes akhir yaitu kelas yang diberikan pembelajaran dengan model pembelajaran kontekstual Komponen Masyarakat Belajar diperoleh nilai sebesar 84. Sedangkan jumlah rata-rata tes awal yang tidak diberikan model diperoleh nilai sebesar 45.

\section{E. KESIMPULAN DAN SARAN}

1. Berdasarkan hasil pengujian hipotesis diketahui bahwa $t_{\text {hitung }}=10,64 \mathrm{dan} \mathrm{db}=$ 60 dalam $t_{\text {tabel }}$ harga $t$ kritiknya terletak pada $0,05=10,64$. Jadi, dinyatakan bahwa $t_{\text {tabel }}<t_{\text {hitung }}=1,67<10,64$ sehingga $t_{\text {hitung }}$ dinyatakan signifikan. Dengan demikian $\mathrm{H}_{0}$ ditolak dan $\mathrm{H}_{\mathrm{a}}$ diterima. Berdasarkan pernyataan tersebut dapat diketahui bahwa, Penggunaan model pembelajaran kontekstual pengaruh yang positif terhadap hasil menulis teks pidato pada siswa kelas XI Madrasah aliyah patra mandiri Palembang.

2. Setelah melakukan penelitian tentang pengaruh model kontekstual memiliki pengaruh yang signifikan terhadap dalam pembelajaran menulis teks pidato, maka peneliti memberikan saran sebagai berikut:

a. Bagi Guru, bidang studi Bahasa Indonesia hendaknya dapat menggunakanmodel kontekstual dalam pembelajaran menulis teks pidato siswa kelas XI Madrasah Aliyah Patra Mandiri Palembang.

b. Bagi siswa, hendaknya hasil penelitian ini dapat dijadikan bahan pengetahuan dan menambah kemampuan dalam menulis teks pidato.

c. Bagi peneliti lain, hendaknya hasil penelitian ini dapat dijadikan informasi dan masukkan sekaligus acuan dalam melakukan penelitian sejenis. 


\section{DAFTAR PUSTAKA}

Aqib, Zainal. 2013. Model-Model, Media, dan Strategi Pembelajaran Kontekstual (Inovatif). Bandung: Yrama Widya.

Arikunto, Suharsimi. 2014. Prosedur Penelitian Suatu Pendekatan Praktik. Jakarta: Rineka Cipta.

Dalman. 2015. Keterampilan Menulis. Jakarta: Raja Grafindo Persada.

Ismawati, Esti. 2012. Bahasa Indonesia untuk Penulisan Karya Ilmiah.Yogyakarta: Ombak (anggota IKAPI).

Komalasari, Kokom. 2014. Pembelajaran Kontekstual.bandung: PT Refika Aditama.

Mairu, Tarmizi dan Eko Silistiyato. 2006. Berpidato. Palembang: CV Karya Agung.

Nurgiyantoro, Burhan. 2010. Penilaian Pembelajaran Bahasa Berbasis Kompetensi Edisi Pertama. Yogyakarta: BPFE-Yogyakarta.

Sudjana, 2005. Metoda Statistika. Bandung: Tarsito.

Sugono dkk, 2013. Kamus Besar Bahasa Indonesia (KBBI). Jakarta: PT Gramedia Pustaka Utama.

Sugiyono. 2017. Metode Penelitian Kuantitatif Kualitatif dan $R \&$ D. Bandung: Alfabeta.

Shoimin. 2014. 68 Model Pembelajaran Inovatif dalam Kurikulum 2013: Yogyakarta: AR-Ruzz Media.

Suprijono, Agus. 2016. Cooperative Learning Teori dan Aplikasi PAIKEM. Yogyakarta: Pustaka Belajar.

Tarigan. 2008. Menulis Sebagai Suatu Keterampilan Berbahasa. Bandung: Angkasa Bandung.

Trianto, 2009. Pengertian Model Pembelajaran (online).

Wardarita, Ratu. 2012. Kemampuan Menulis Karya Ilmiah. Palembang: Universitas PGRI Palembang.

Wiyanto, Asul. 2012. Kitab Bahasa Indonesia. Yogyakarta: Yogya Bangkit Publisher (anggota IKAPI). 